\title{
BELAJAR MENGAJAR DARI PENGAJARAN YESUS
}

\section{Hadi P. Sahardjo}

\section{ABSTRAK}

Mengajar bukan sekedar melaksanakan tugas. Mengajar perlu bekal yang memadai. Mengajar bukan asal menyampaikan materi pembelajaran kepada peserta didiknya. Bukan sekedar menyampaikan bahan pengajaran dan menransfer ilmu. Mengajar juga bukan sekedar kemampuan serta penguasaan materi pembelajaran, namun perlu keterampilan dan penguasaan metode pengajaran yang baik dan tepat guna. Bukan sekadar menonjolkan kemampuan otak, tetapi berkaitan dengan sentuhan hati dan nurani. Pembelajaran seperti ini akan menjadikan setiap individu pebelajar bisa mengalami transformasi kehidupan secara utuh. Itulah sebabnya seorang pendidik perlu belajar dari Tuhan Yesus sebagai model pembelajar dan pengajar yang sesungguhnya.

Frasa kunci: pendidik, peserta didik, belajar, mengajar, pembelajaran, metode pengajaran, transformasi kehidupan.

\section{PENDAHULUAN}

Mengajar itu sepertinya mudah, padahal sulit. Atau kalau mau dibalik, mengajar itu sulit, padahal mudah. Tentunya itu tergantung situasi, kondisi dan domisili. Oleh karena itu dalam mengajar mesti memerhatikan seluruh komponen pembelajaran-mulai dari pengajar/pendidik, yang diajar/murid/peserta didik, materi pembelajaran, metode pembelajaran, sarana-prasarana pembelajaran, lokasi pembelajaran (termasuk di dalamnya lingkungannya), situasinya, waktunya, kesiapannya, dst. Oleh karena itu satu materi pembelajaran dengan bahan yang sama, metode pendekatannya 
sama, tetapi diajarkan oleh orang yang berbeda dengan peserta didik yang berbeda di tempat yang berbeda, hasilnya belum tentu sama. Itulah sebabnya pendidikan itu dikatakan sebagai suatu seni. Maknanya, hasil akhir dan capaian tujuan pengajaran itu akan sangat tergantung dari faktor-faktor tersebut yang saling berkaitan antara yang satu dengan yang lainnya.

Hal lain yang perlu mendapat perhatian adalah terkait dengan soal tugas dan fungsi pendidikan Kristen. Menurut Pazmiño dalam bukunya, "Foundational Issues in Christian Education," pendidikan Kristen itu pada dasarnya memiliki lima tugas atau fungsi utama, yaitu pendidikan dengan fungsi proklamasi (kerygma), pendidikan dengan fungsi untuk memberikan suatu dukungan atau advokasi (propheteia), pendidikan dengan fungsi pelayanan (diakonia), pendidikan dengan fungsi persekutuan(koinonia) dan pendidikan dengan fungsi ibadah (leitourgia), yang meliputi iman, pengharapan, kasih dan persekutuan. ${ }^{1} \quad$ Itu berarti bahwa dalam pendidikan Kristen, lebih-lebih pendidikan teologi, arah pendidikan harus benar-benar menjadikan para peserta didik untuk menjadi manusia seutuhnya dan insan Kristen yang sebenarnya sebagaimana dimaksudkan oleh Pazmiño. Dalam hal ini peran seorang pendidik sangatlah penting.

\section{YESUS SEBAGAI PENDIDIK}

Dalam kitab Injil Sinoptik (Matius, Markus, Lukas) dan Yohanes, terdapat hingga sebanyak 45 kali sebutan Tuhan Yesus

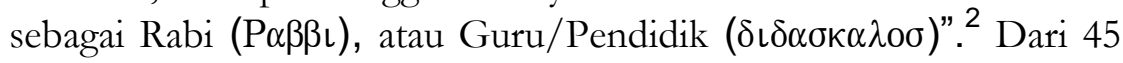
kali sebutan itu, sebagian besar panggilan atau penyebutan dilakukan oleh orang-orang di sekitar-Nya, tetapi adakalanya Tuhan Yesus juga menyebut diri-Nya demikian, sebagaimana dikatakan kepada para

${ }^{1}$ Robert w. Pazmiño, Foundational Issues in Christian Education (Grand Rapids, Michigan: Baker Books, 2004), 45 ff.

2 Robert H. Stein, The Method and Message of Jesus Teachings, (Louisville, Kentucky: Westminster John Knox Press, 1994), 1 dyb. 
murid-Nya, "Tetapi kamu, janganlah kamu disebut Rabi, karena hanya satu Rabimu dan kamu semua adalah saudara" (Matius 23:8, bdk. 10:24-25 dan Yohanes 13:13-14). Dalam bahasa Yunani

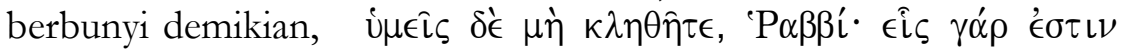

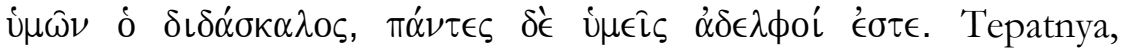
kalau diterjemahkan ayat itu berbunyi, “Tetapi janganlah kamu dipanggil Rabi (P $\alpha \beta \beta \iota)$, karena Guru/Pendidik ( $\delta\llcorner\delta \alpha \sigma \kappa \alpha \lambda \circ \sigma) \mathrm{mu}$ hanya ada satu, dan kalian semua adalah saudara-saudara." Dengan kata lain di sini Tuhan Yesus hendak memberitahukan kepada para murid, bahwa hanya Dialah satu-satunya "pendidik" yang benarbenar dan sejati. ${ }^{3}$ Menurut penulis, ini sangat tepat, karena selaku Pendidik, Tuhan Yesus tidak hanya mengajarkan kebenaran, melainkan melakukan kebenaran, karena Dia sendiri adalah kebenaran itu." (Yohanes 14:6).

Pendidik selalu dipandang sebagai orang yang pandai, serba tahu, serba bisa, penuh hikmat dan tempat orang mengadu dan bertanya untuk memeroleh jawaban. Seorang pendidik adalah tempat di mana orang minta saran atau pendapat guna mendapatkan kepastian jawaban dan jaminan. Lukas 3:12 mencatat bahwa Yohanes Pembaptis juga dipanggil sebagai "pendidik" oleh pemungut-pemungut cukai yang datang kepadanya untuk dibaptis dan mereka bertanya kepadanya: "Pendidik, apakah yang harus kami perbuat?" Dalam kitab Markus 10:17 juga dijumpai hal yang sama yang ditujukan kepada Yesus, ketika ada sedang dalam perjalanan datanglah seorang berlari-lari mendapatkan Dia dan sambil bertelut di hadapan-Nya ia bertanya: "Guru yang baik, apa yang harus kuperbuat untuk memeroleh hidup yang kekal?" Kalau demikian, siapakah guru atau pendidik itu?

${ }^{3}$ Dalam hal ini Alkitab terjemahan New Revised Standard Version dan Alkitab Terjemahan BIS lebih tepat jika dibandingkan dengan Alkitab terjemahan New International Vesion (NIV) maupun Alkitab Terjemahan Baru (TB-LAI). 
Tentang pendidik, Klausmeier ${ }^{4}$ menuliskan demikian, "The teacher, too, serves as a stimulus for the learners. They are aware not only of the teacher's personal appearance, but also of his speech and actions. Terjemahan bebasnya kurang lebih artinya demikian, "Seorang pendidik yang mengajar itu menjadi suatu stimulus bagi para peserta didiknya. Para peserta didik akan disadarkan bahwa bukan hanya penampilan pribadi pendidik-yang memengaruhi mereka, melainkan juga ucapan dan tindakan-tindakannya". Dengan kata lain, pendidik sebagai the whole person menjadi contoh dan teladan bagi para peserta didiknya, baik itu kepribadiannya, cara hidupnya, maupun perkataan dan perbuatannya. Semua ini bagaikan cermin bagi para peserta didik. Jadi, pendidik itu harus mengajar dengan keseluruhan pribadinya, bukan hanya dari perkataannya, tetapi dari perbuatan atau teladan hidupnya. “... sama seperti Anak Manusia datang bukan untuk dilayani, melainkan untuk melayani dan untuk memberikan nyawa-Nya menjadi tebusan bagi banyak orang." (Matius 20:28).

Memang, tugas utama seorang pendidik adalah mengajar atau memberikan kuliah. Mengajar tidak bisa dilepaskan dengan metode yang harus digunakannya. Sekarang ini telah banyak metode yang ditawarkan oleh para ahli maupun para praktisi pendidikan. Tetapi bisa ditemukan metode-metode penting yang terdapat di dalam Alkitab, khususnya melalui pengajaran yang dilakukan oleh Tuhan Yesus dalam kitab Injil, jauh sebelum para ahli modern mengemukakan metode-metode pengajaran yang mereka tawarkan. Penulis sependapat dengan Stein yang memandang pentingnya penggunaan metode yang baik, tepat dan benar dalam pengajaran. ${ }^{5}$ Sebab meskipun materinya baik, penguasaannya bagus, tetapi jika seorang pendidik tidak memiliki kemampuan penggunaan metode secara tepat dan benar, maka hasil dan tujuan pendidikan pun tidak akan tercapai secara optimal.

${ }^{4}$ Herbert J. Klausmeier, Learning and Human Abilities (New York and London: Harper \& Row, Publishers, 1966), 164.

${ }^{5}$ Stein, 7. 


\section{Pendekatan-pendekatan dalam Pengajaran Yesus}

Selama hidup dan pelayanan-Nya di dunia ini, Tuhan Yesus banyak menggunakan pendekatan yang berbeda. Cornelius Jaarsma ${ }^{6}$ dalam bukunya, "Human Development, Learning and Teaching" menjelaskan, bahwa mengajar itu bukan sekedar menyampaikan pesan (materi pengajaran) kepada murid (peserta didik), di mana pendidik bertindak sangat aktif, atau sebaliknya menjadikan peserta didik sebagai objek yang pasif dengan menjejali ilmu-ilmu agar dipahami oleh mereka, padahal mungkin hal itu bukan yang dibutuhkan. Jaarsma mengutip sebuah pepatah yang mengatakan, "You can lead a horse to the water, but you cannot make him drink." (Anda bisa menuntun kuda ke dalam air, tetapi Anda tidak bisa memaksanya untuk minum). Pesan yang hendak disampaikan adalah, bahwa seorang pendidik tidak bisa memaksakaan kepada para murid atau peserta didik untuk melakukan sesuatu jikalau mereka tidak merasa memerlukan atau ketahui. Sehingga tugas pendidik atau pendidik adalah menjadikan mereka merasa memerlukan dengan jalan memberikan kepada mereka hal-hal yang menarik dan menyenangkan. Oleh karena itu dalam mengajar tidak boleh hanya sekedar memaparkan materi pelajaran tanpa arah tujuan yang jelas. Pendekatan-pendekatan yang dilakukan oleh Tuhan Yesus dalam pengajaran-Nya dapat dilihat antara lain dari hal-hal berikut ini:

\section{Mengadakan Kontak Pribadi dengan Murid}

Seringkali seorang pendidik menganggap peserta didik itu hanya sebagai sasaran pembelajarannya, sehingga menjadikannya sebagai objek yang pasif. Seorang pendidik seharusnya selalu

${ }^{6}$ Cornelius Jaarsma, Human Development, Learning and Teaching (Grand Rapids, Michigan: Wm. B. Eerdmans Publishing Company, 1961), 243-245.

${ }^{7}$ Ibid, 245. 
memiliki tanggapan yang positif terhadap peserta didik. Tidak boleh memandang peserta didik sebagai objek didik, tetapi subjek didik yang mampu bertindak aktif dan kreatif. Hal inilah yang dilakukan oleh Tuhan Yesus dalam kegiatan pengajaran-Nya. Ketika Tuhan Yesus duduk di tepi sumur dalam perjalanan-Nya dari Yudea ke Galilea, Dia bertemu dengan seorang perempuan Samaria (Yohanes 4:1-42.) yang sedang mengambil air di sumur itu. Karena tidak biasanya orang mengambil air pada siang hari, maka terjadilah kontak pribadi antara Tuhan Yesus dengan perempuan Samaria tersebut. Ada beberapa hal yang dilakukan oleh Tuhan Yesus dalam percakapan itu, yang didahului dengan permintaan-permintaan pribadi.

Menurut LeBar, ada beberapa hal yang harus kita pikirkan terkait dengan tujuan Yesus memulai pelajaran-Nya dengan permohonan yang sifatnya pribadi ini, yaitu: Pertama, Dia menimbulkan keingintahuan dan pertanyaan-pertanyaan. Kedua, Dia membangkitkan minat orang akan diri-Nya sebagai satu Pribadi. Ketiga, Dia mengidentifikasikan diri-Nya dengan kewajiban yang diemban oleh murid-Nya. Keempat, Dia memberikan kesempatan kepada perempuan itu untuk menanggapi secara aktif. ${ }^{8}$ Jika hal seperti ini dilakukan dalam perkuliahan, maka kontak pribadi semacam ini bisa memberikan dampak positif bagi peserta didik, karena mereka merasa diperhatikan-baik secara pribadi maupun kelompok--sehingga setiap individu akan merasakan bahwa mereka adalah sebagai satu bagian dari kelompok yang tidak akan terpisahkan.

\section{Mengajak Murid Terlibat Secara Aktif}

Berhubungan dengan mengajar, LeBar mengatakan bahwa Tuhan Yesus telah berhasil melakukan hal ini melalui kecakapan-Nya yang sempurna dengan jalan membawa para murid-Nya keluar dari rutinitas kesehariannya kepada kehidupan kekal. ${ }^{9}$ Seorang pendidik

${ }^{8}$ Lois E. LeBar, Education that Is Christian (terj.) (Malang: Gandum Mas, 2006), 77.

${ }^{9}$ Ibid. 79. 
harus mampu menjadikan peserta didik aktif dan menimbulkan motivasi yang kuat untuk belajar. Memang, setelah terjadi kontak pribadi, peserta didik harus dilibatkan dan diberikan peran aktif yang disertai dengan pemberian petunjuk atau perintah-perintah yang bisa dimengerti dan diterima oleh peserta didik. Peserta didik juga harus diberikan kesempatan untuk mengeksplorasi diri, dan itu perlu diberikan apresiasi atau penghargaan. Dengan demikian maka peserta didik juga telah belajar untuk disiplin dan taat.

\section{Memenuhi Kebutuhan Rohani Murid}

Pendidik harus menyadari bahwa kebutuhan yang paling utama dan mendasar dari peserta didik sebenarnya bukan soal intelek semata-mata, melainkan kebutuhan rohani atau spiritual. Soal perempuan Samaria tadi. Tuhan Yesus tidak mau terlibat terlalu banyak dengan masalah kebutuhan hidup jasmani dan soal rumah tangganya. Tetapi Tuhan Yesus langsung mengarahkan pembicaraan yang menyangkut soal kebutuhan hidup yang paling bernilai, yaitu kebutuhan rohani, keselamatan. Karena itu percakapan lalu beralih kepada soal iman/ kepercayaan. Itulah sebabnya maka menurut Benson, ${ }^{10}$ dalam pembelajaran-baik tujuan, materi maupun aktivitas-aktivitas-harus selalu dibangun dan berdasarkan pada firman Tuhan.

Pada kenyataannya, saat ini banyak sekolah teologi-baik di dalam maupun di luar negeri-yang tidak mendidik, mengajar dan memersiapkan para peserta didik untuk menjadi seorang hamba Tuhan yang mengasihi dan melayani Tuhan, melainkan hanya memberikan ilmu. Sehingga bisa jadi peserta didik sangat pandai mengenai filsafat, teologi, bahasa-bahasa asli bahkan mungkin

10 Clarence H. Benson, Sunday School Succes (Wheaton, Illinois: Evangelical Teacher Training Education, 1976), 68. 
analisis dan tafsir Alkitab, namun itu sebatas pada teori yang mengisi otak dan bukan kebenaran firman Tuhan yang mengisi hati.

\section{Membuat Kebenaran Itu Berlaku Atas Diri Murid}

Dalam hal perempuan Samaria tadi, Tuhan Yesus tidak hanya mengajar supaya dia mengerti, tetapi juga memiliki. Langkah yang diambil perempuan tadi sangat luar biasa. Dia percaya kepada Yesus, bahkan akhirnya mengajak orang-orang sedesanya datang kepada Yesus. Oleh karena itu pertanyaan LeBar terkait hal ini adalah, "Apakah cukup hanya minta murid untuk bisa menceritakan kembali apa yang telah kita ajarkan?"11 Jawabannya tentu saja tidak cukup. Mereka harus tahu dan mau melakukannya. Sehingga kebenaran atau ilmu yang dimiliki pun tidak hanya dimiliki sendiri, melainkan juga dibagikan kepada orang lain. Kesaksian perempuan Samaria itu sangat efektif, sehingga orang-orang dari kota datang kepada-Nya, di mana banyak di antara mereka yang kemudian percaya kepada-Nya. Tetapi masih lebih banyak lagi yang percaya karena mendengarkan perkataan-Nya. ${ }^{12}$

Dalam pengajaran-Nya, Tuhan Yesus selalu menghendaki agar apa yang telah mereka ketahui itu bisa dilaksanakan dalam kehidupannya, bukan hanya disimpan di otak. Bukan pemahaman secara teoretis, melainkan penalaran aplikatif. Kalimat-kalimat seperti “... pergilah, perbuatlah demikian" itu muncul berkali-kali dalam Injil Sinoptik, seperti dalam Matius 7:12; Lukas 10:28; Lukas 10:37 dll.

\section{Melakukan Sesuai dengan Situasi, Kondisi dan Kebutuhan}

Ketika Tuhan Yesus menyembuhkan orang-orang yang buta, Dia melakukan dengan cara berbeda, karena latar belakang mereka memang juga berbeda. Setidak-tidaknya ada empat drama penyembuhan orang buta yang dilakukan oleh Tuhan Yesus, yaitu penyembuhan dua orang buta (Matius 9:27-34); penyembuhan
${ }^{11}$ LeBar, 84.
12 Ibid. 
seorang buta di Betsaida (Markus 8:22-26); penyembuhan dua orang buta di Yerikho (Matius 20:29-34; Markus 10:46-52 dan Lukas 18:3543) serta penyembuhan seorang yang buta sejak lahirnya (Yohanes 9:1-41). LeBar mencoba untuk menjelaskan dengan melukiskannya dalam sebuah tabel demikian: ${ }^{13}$

Matius 9:27-34 1 paragraf $\begin{aligned} & \text { Dalam satu satuan kurikulum } \\ & \text { mengenai iman. }\end{aligned}$

Markus 8:22-26 1 paragraf Dalam satuan kurikulum mengenai pengetahuan siapa Yesus sebenarnya.

Yohanes $9 \quad 1$ pasal

Matius 20:29-34 Masing-

Markus 10:46-52

Lukas 18:35-43 masing 1 paragraf

Dalam satu satuan kurikulum mengenai pengetahuan tentang karya-Nya.

Dalam satu satuan kurikulum mengenai yang terdahulu sebagai yang terkemudian dan yang terkemudian sebagai yang terdahulu.

Sebenarnya pada intinya LeBar ingin menjelaskan bahwa masing-masing kejadian ini memiliki pesan tersendiri. Meskipun ia menyadari bahwa untuk menyebutkan adanya satuan-satuan kurikulum dalam hubungannya dengan Injil itu bisa membingungkan banyak pihak. LeBar menjelaskan bahwa Tuhan Yesus tidak memerlakukan semua orang buta itu dengan cara yang sama. Hal ini dilatarbelakangi oleh keadaan mereka yang berbeda pula. $^{14}$ Orang buta yang dicatat dalam Matius 20:29-34, Markus 10:46-52 dan Lukas 18:35-43 menunjukkan kesiapan imannya,
${ }^{13}$ LeBar, 89.
${ }^{14}$ Ibid. 
sehingga Tuhan Yesus cukup mengatakan, “... imanmu telah menyelamatkan engkau!” (Markus 10:52). Selanjutnya dalam Matius 9:27-34 juga dikisahkan tentang dua orang buta yang secara aktif meminta dan datang kepada Yesus, bahkan sampai ikut masuk ke dalam rumah di mana Tuhan Yesus berada.

Di sini Tuhan Yesus tidak sekedar menjamah, tetapi juga mengucapkan kalimat, "Jadilah kepadamu menurut imanmu." (Matius 9:29). Sedangkan yang dicatat dalam Yohanes pasal 9 tidak menunjukkan keinginan pribadi orang yang buta sejak lahirnya itu . Dia tidak minta Tuhan Yesus untuk memelekkan matanya. Malah orang-orang membincangkannya, yang mengaitkan dengan dosa turunan atau dosa pribadi (ayat 2). Namun Tuhan Yesus menjelaskan bahwa kebutaan itu tidak disebabkan oleh dosa siapa pun, melainkan supaya pekerjaan Allah dinyatakan dan nama Tuhan dimasyhurkan (ayat 3). Oleh karena itu meskipun tanpa permintaan oleh siapa pun Tuhan Yesus tetap memelekkan mata orang buta itu, karena Dia tahu akan kebutuhan orang buta itu. Nyatanya, seluruh pasal itu akhirnya memuat kesaksian orang buta yang dicelikkan matanya oleh Tuhan Yesus itu kepada setiap orang yang dijumpainya. Pendek kata, Tuhan Yesus melakukan cara pendekatan yang berbeda untuk menghadapi kasus yang nampaknya sama, namun pada hakikatnya berbeda. Tepat sekali apa yang dikatakan oleh LeBar tentang hal ini seperti berikut:

... mudah untuk diketahui mengapa Tuhan memakai alat atau cara dalam dua kasus, dan tidak memakainya dalam dua kasus yang lain. Jika orang-orang itu tidak mengenal Dia dan kuasa-Nya, mereka membutuhkan cara untuk mengembangkan iman mereka melalui hubungan pribadi dengan Dia. Dia menggunakan alat-alat fisik bukan karena Dia membutuhkannya, melainkan karena mereka membutuhkan alat-alat itu. ${ }^{15}$

15 LeBar, 96. 
Ini semua dilakukan oleh Tuhan Yesus karena Dia berusaha untuk memenuhi berbagai kebutuhan sampai pada tingkat kehidupan yang diciptakan-Nya. ${ }^{16}$

\section{HAKIKAT Metode PENGAJARAN Yesus}

Sebagaimana telah disinggung dalam latar belakang masalah, ada beberapa metode penting yang dipakai oleh Tuhan Yesus dalam pelayanan dan pengajaran-Nya selama di dunia ini. Choun, Jr, mengatakan bahwa selaku Pendidik yang sangat sempurna, Tuhan Yesus adalah satu teladan yang paling tepat dalam memilih dan menerapkan metode-metode atau model pengajaran yang kreatif dan inovatif. ${ }^{17}$ Choun mendaftarkan ada duapuluh cara pendekatan yang sangat kreatif yang dilakukan oleh Tuhan Yesus dalam pengajaran dan pelayanan-Nya. ${ }^{18}$ Dari keduapuluh cara pendekatan ini delapan di antaranya diambil dari contoh yang terdapat dalam Injil Yohanes, dan duabelas lainnya bersumber dari Injil Sinoptik. Untuk memersingkat, penulis hanya akan mengutip beberapa hal yang penting, khususnya yang bersumber dari Injil Sinoptik seperti berikut ini:

Pertama, memecahkan masalah (Markus 10:17-22)-untuk menggerakkan orang-orang agar dapat memahami dan menerapkan kata-kata Yesus.

Kedua, percakapan (Markus 10:27)_untuk menggerakkan orang-orang kepada ketaatan

16 Ibid., 117.

17 Robert Joseph Choun, Jr. "Choosing and Using Creative Methods" dalam The Christian Educator's Handbook on Teaching (3rd Edition). Eds. Kenneth O. Gangel \& Howard G. Hendricks (Grand Rapids, Michigan: Baker Books, 2003), 166.

18 Ibid, 166-168. 
Ketiga, pertanyaan-pertanyaan — seperti yang terekam dalam kitab-kitab Injil, Yesus mengajukan lebih dari 100 pertanyaan dengan tujuan membangkitkan para pendengar-Nya untuk berpikir dan mencari kebenaran yang terkandung di dalamnya.

Keempat, menjawab-Tuhan Yesus menggunakan jawaban untuk menggerakkan orang-orang agar menyadari keberadaannya dan apa yang mereka perlukan agar mengalami pertumbuhan secara rohani. Yesus mendorong orang-orang agar bisa menemukan kebenarannya.

Kelima, ceramah atau "kuliah" (Matius 5-7)_-Tuhan Yesus menggunakan ceramah untuk memberikan perintah atau instruksi dengan meyakinkan orang-orang di dalam kebenarannya.

Keenam, pemakaian Kitab Suci (Matius 4:1-11;22:37 dyb., dll)_dalam mengajar, Tuhan Yesus banyak mengutip Perjanjian Lama untuk menyampaikan tentang kebenaran Allah.

Ketujuh, kontras (Matius 5:21-22, 33-34, 38-39, 43-44)Tuhan Yesus membandingkan Kerajaan-Nya dengan prinsipprinsip dunia, memberikan kepada para pendengar suatu pilihan untuk taat atau menolak.

Kedelapan, simbol-simbol atau lambang (Matius 26:17-30); Yohanes 13:1-20)_Tuhan Yesus menggunakan lambang, seperti pada waktu melaksanakan perjamuan Paskah sebelum kematian-Nya, Dia mencuci kaki para murid-Nya, untuk mengajar pelajaran-pelajaran besar.

Kesembilan, keteladanan (Matius 15:32; Lukas 18:15-17)Yesus sebagai Pendidik Agung, adalah Kebenaran dan menjadikan Dia sebagai teladan selaku Anak Manusia yang mencintai Allah Bapa-Nya.

Kesepuluh, motivasi (Matius 16:24-27; 20:21-28; Markus 1:1618)_-Yesus memotivasi/mendorong para pengikut-Nya untuk mengambil suatu langkah atau tindakan. Ia membangkitkan respons pendengar-Nya untuk mengasihi dan taat ke Bapa. 
Kesebelas, kesan dan ungkapan (Matius 4;19-20; 7:20)_Yesus memakai diri-Nya untuk menjadikan murid-Nya terkesan sehingga memotivasi mereka untuk bertindak dan taat. Tuhan Yesus adalah Allah yang menjadi manusia, sehingga Ia membantu para murid-Nya untuk membuat keputusan bagi diri mereka.

Keduabelas, melalui diri-Nya (Matius 28:19-20)_Tuhan Yesus memiliki kualitas sebagai seorang Mahapendidik: ada visi global, memahami manusia, menguasai semua pengetahuan, kemampuan dalam mengajar, dan suatu kehidupan yang patut dijadikan contoh kepada mereka yang diajar.

Dari sini nampak jelas bagaimana totalitas Yesus selaku Pendidik yang melakukan pengajaran dengan seluruh aspek kehidupan dan diri-Nya, agar para murid atau orang-orang yang menerima pengajaran-Nya dapat memahami dan menerima sepenuhnya untuk dilaksanakan dalam kehidupan mereka sehari-hari.

\section{Karakteristik Pengajaran Yesus}

Sebagai seorang pribadi dan manusia sejati, Tuhan Yesus adalah sumber paling penting untuk motivasi setiap individu, termasuk pendidik. Dalam pengajaran-Nya, Tuhan Yesus memiliki karakteristik-karakteristik yang tidak terdapat pada tokoh pendidikan mana pun. Beberapa di antara karakteristik pengajaran Yesus yang terpenting, adalah: ${ }^{19}$

\section{Adanya Otoritas}

Otoritas yang dimiliki oleh Tuhan Yesus diakui oleh para murid, bahkan musuh-musuh-Nya sekalipun, bahwa Dia memang

19 Leon Marsh, Educational Psychology for Christian Education (Fort Worth, Texas: Southwestern Baptist Theological Seminary, 1982), 260-261. 
memiliki kuasa dan otoritas. Karena Ia bisa melakukan perkaraperkara besar yang tidak bisa dilakukan oleh orang lain, maka orangorang berkomentar bahwa tindakan dan perkataan-Nya memiliki kuasa (Matius 7:28-29). Sehingga tidak mengherankan kalau orangorang yang selama ini memusuhi-Nya (orang-orang Farisi, Saduki, imam-imam kepala, para ahli Taurat dan tua-tua) sampai harus memertanyakan tentang kuasa yang dimiliki oleh Tuhan Yesus (Matius 7:28-29). Otoritas Yesus yang besar itu tentu bukan datang dengan sendirinya. Selain karena Dia adalah Anak Allah, tetapi juga memiliki penuntutan yang luar biasa. Dia mengawali pelayanan-Nya dengan berpuasa selama empat puluh hari empat puluh malam (Matius 4:2). Injil Lukas 2:41-52 juga mencatat tentang Yesus yang baru berusia duabelas tahun sedang berdiskusi dengan para tokoh agama dan ahli Kitab di dalam Bait Allah. Di sana Dia juga sedang bersoal-jawab tentang Alkitab. Paling tidak ada sembilan kali dalam Injil Sinoptik disebutkan bahwa Tuhan Yesus secara langsung menyebut nama Kitab Suci sebagai referensi dalam pengajaran-Nya. Tentu saja, meskipun tidak seperti Tuhan Yesus, tetapi sebagai pendidik sekolah teologi yang sudah mengalami lahir baru juga harus memiliki kuasa Tuhan Yesus.

\section{Adanya Kewajaran dan Keaslian.}

Tuhan Yesus selalu tampil secara wajar dan apa adanya. Dia bisa marah kalau memang harus marah-misalnya ketika harus mengusir orang yang berjual beli di Bait Allah (Matius 21:12-17) -atau ketika Petrus melarang Tuhan Yesus untuk pergi ke Yerusalem untuk menderita (Matius 16:22-23). Tetapi pada bagian lain Tuhan Yesus lebih banyak menunjukkan sikap kasih dan lemah lembutNya, seperti yang dilakukan-Nya terhadap Yakobus dan Yohanes ketika sepuluh murid-Nya yang lain memarahi mereka karena minta suatu kedudukan jika kelak sudah berada di surga. Tidak ada kepalsuan pada diri-Nya. Sifat kewajaran (genuineness) semacam ini sudah seharusnya ada pada setiap pendidik Kristen (termasuk dosen sekolah teologi), baik itu di gereja maupun di sekolah; karena para pendidik itu menjadi cermin hidup yang dilihat dan disaksikan oleh banyak pihak, seperti awan yang mengelilingi kita (Ibrani 12:1). 


\section{Adanya Kekuatan Nalar dan Alasan.}

Ketika Tuhan Yesus berbicara atau beragumentasi dengan banyak kalangan, Ia selalu memakai nalar dan alasan yang masuk akal, sehingga tidak ada seorang pun yang mampu mendebat-Nya. Kebanyakan mereka lalu menjadi bungkam. Misalnya saja ketika orang-orang Farisi dan para ahli Taurat yang membawa perempuan berzina yang diperhadapkan kepada Tuhan Yesus dengan maksud untuk mencari kesalahan-Nya. Alih-alih mengalahkan Tuhan Yesus, mereka justru akhirnya ditempelak dengan dosa mereka sendiri, ketika mereka tidak berani melempari perempuan itu dengan batu, karena mereka adalah juga orang-orang yang berdosa (Yohanes 7:538:11). Seorang pendidik juga harus belajar memiliki nalar sedemikian sehingga tidak dipermainkan, melainkan dihormati para peserta didiknya.

\section{Adanya Hubungan Pribadi dengan Murid.}

Salah satu sifat yang paling menonjol dalam diri Tuhan Yesus adalah hubungan pribadi-Nya dengan para murid yang sedemikian akrab dan hangat. Sepanjang hidup pelayanan-Nya, siang dan malam, Dia hampir selalu bersama dan berada di tengah-tengah para murid, baik dalam keadaan susah maupun senang, aman maupun bahaya. Dari situ pun para murid dapat belajar banyak secara langsung dari kehidupan Tuhan Yesus yang tidak ada satu pun yang tersembunyi.

Sesungguhnya kehadiran dan kebersamaan itulah yang menjadikan mereka tenang, bahkan tinggal di mana pun Yesus tinggal-meskipun "tidak ada tempat" bagi-Nya untuk meletakkan kepala-Nya (Matius 8:20; Lukas 9:58). Dalam kebersamaan Tuhan Yesus juga mengenal sifat para murid secara pribadi, demikian sebaliknya. Itulah sebabnya maka murid-murid tidak hanya belajar dari-Nya dan mengenal Dia, melainkan juga bisa menerapkan pengajaran Tuhan Yesus dalam kehidupan praktis dan pelayanan mereka. Dalam kebersamaan-Nya ini Tuhan Yesus juga tidak 
segan-segan memuji (Matius 16:17), atau sebaliknya menegur jika melakukan suatu kesalahan atau bersikap tidak tepat (Matius 16:23). Oleh karena itu para murid takut "kehilangan" Dia sehingga Petrus mengatakan akan berjuang dan membela mati-matian terhadap orang-orang yang mencoba "mencelakai-Nya", meskipun sikap Petrus (dan juga murid-murid lainnya) justru tidak mendapatkan pujian dari Tuhan Yesus, bahkan sebaliknya (Matius 26:30-35; 47-56; Markus 14:47-56; Lukas 22:47-53).

\section{Ciri-ciri Pengajaran Yesus}

Ketika menjelaskan tentang "Hukum Mengajar" dari tujuh hukum yang ditulis oleh Gregory, ${ }^{20}$ dia menandaskan agar para pendidik memberikan rangsangan dan pengarahan kepada aktivitasaktivitas pribadi murid, dan sedapat mungkin jangan memberitahukan apa pun kepada murid sesuatu yang dapat dipelajari sendiri. ${ }^{21}$ Ini merupakan salah satu bentuk teknik dari pembelajaran. Tuhan Yesus juga menerapkan teknik-teknik seperti itu. Tetapi yang jelas bahwa teknik-teknik pengajaran yang dipakai oleh Tuhan Yesus selalu bertujuan untuk memberikan motivasi kepada para pendengarnya. Berikut ini penulis sarikan penjelasan Leon Marsh terkait dengan teknik Tuhan Yesus dalam pengajaranNya seperti berikut: ${ }^{22}$

Pertama, Yesus menggunakan teknik bertanya. Tuhan Yesus menggunakan teknik bertanya secara langsung kepada para pengikut-Nya untuk mencapai keberhasilan memotivasi mereka. Dalam Alkitab terdapat lebih dari 100 pertanyaan yang dipakai oleh Tuhan Yesus. Misalnya untuk menegur suara hati orang-orang Farisi dan ahli-ahli Taurat (Matius 23:17); menantang iman mereka

20 Almarhum John Milton Gregory adalah Dekan Pertama pada Universitas Illinois, yang menulis buku The Seven Laws of Teaching yang diterbitkan pertama kali dalam bahasa Inggris pada tahun 1884.

21 John Milton Gregory, Tujuh Hukum Mengajar (terj.) (Malang: Gandum Mas, t.t.), 103.

22 Marsh, 261-264. 
(Markus 8:29); untuk membungkam kritikan (Markus 10:3); untuk mengungkit perasaan Nikodemus (Yohanes 3:10), untuk memaksa agar mereka berpikir (Matius 21:28-32), dll.

Kedua, kemampuan untuk menarik dan menguasai perhatian. Tuhan Yesus menggunakan banyak cara untuk menarik perhatian. Dia biasa menggunakan alam dalam memberikan penjelasan pengajaran-Nya untuk menarik perhatian pendengar. Misalnya tentang penabur, pohon ara, bunga di padang, burungburung, dsb. Kata-kata yang biasa digunakan seperti, "Behold" "Lihatlah!" "23atau, "kamu telah mendengar..." (Matius 5:21, 27, 33, 38, 43), dll.

Ketiga, menekankan pada hal-hal yang positif. Tuhan Yesus banyak mengutip dan menjelaskan Perjanjian Lama untuk memberikan penerapan aplikasi positif bagi para pendengar. Kadang-kadang Ia juga menggunakan aspek negatif terhadap hukum Musa dengan mengatakan, "janganlah kamu ..." ataupun secara positif, "hendaklah kamu ..." atau ucapan senada, misalnya, "Kasihilah Tuhan Allahmu dengan segenap hatimu, dan... kasihilah sesamamu seperti dirimu sendiri”" (Matius 22:37-40).

Keempat, Dia menggunakan hal-hal yang gampang dimengerti untuk menjelaskan hal-hal yang sulit dipahami. Tuhan Yesus misalnya, menjelaskan bagaimana relasi yang terjalin antara murid dengan pendidiknya itu ibarat carang yang harus tetap lekat pada pokok anggurnya (Yohanes 15:1-5); pohon ara yang tidak berbuah untuk melukiskan orang percaya yang tidak berbuahkan iman yang benar (Lukas 13:6); perumpamaan kambing dan domba untuk menunjukkan orang-orang yang baik dan jahat/orang percaya dan orang berdosa (Matius 25:31-46), dll.

${ }^{23}$ Matius13:3, ASV, NAS, NKJ, GNV dll. 
Kelima, Dia menggunakan contoh-contoh yang konkret. Misalnya untuk mengajarkan tentang pemeliharaan Allah Dia memakai burung sebagai lukisan, kerendahan hati, Dia menunjuk pada anak-anak, untuk menunjukkan bahwa Dia tidak membedabedakan orang, maka Dia makan dengan mereka, termasuk orang berdosa, seperti makan di rumah Zakheus, dll.

Keenam, Tuhan Yesus memakai hal-hal yang menakutkan untuk membuat perbandingan. Tuhan Yesus membandingkan dengan hal-hal yang menakutkan untuk memotivasi para pendengar agar merenungkan apa yang seharusnya dilakukan (Matius 26:24).

Ketujuh, Tuhan Yesus memakai sifat keingintahuan para murid untuk memberi motivasi kepada mereka agar dapat melakukan hal yang sama. Misalnya Dia mencontohkan tentang Natanael sebagai orang yang tidak memiliki tipu daya (tulus) di seluruh Israel. Atau memberikan contoh diri-Nya ketika Dia mengatakan, "Makanan-Ku ialah melakukan kehendak Dia yang mengutus Aku, dan menyelesaikan pekerjaan-Nya' (Yohanes 4:34).

Kedelapan, Tuhan Yesus menggunakan perumpamaanperumpamaan atau lukisan untuk menjelaskan apa yang dikatakan-Nya dengan maksud agar kebenaran yang dikatakan-Nya itu menjadi jelas. Sebagaimana telah disinggung di bagian depan menurut Stein, ${ }^{24}$ Tuhan Yesus menggunakan simile ketika menegur orang Farisi yang munafik dilukiskan sebagai "kubur yang bersapu kapur, padahal di dalamnya tulang-belulang" (Matius 23:27), atau menggunakan metafora, "... pergilah kepada domba-domba yang hilang dari umat Israel" (Matius 10:6) atau hiperbola, "Hai kamu pemimpin-pemimpin buta, nyamuk kamu tepiskan dari dalam minumanmu, tetapi unta di dalamnya kamu telan" (Matius 23:24) atau epigram, misalnya, "Yang terakhir akan menjadi yang terdahulu, dan yang terdahulu akan menjadi yang terakhir" (Matius 20:16). Ia juga memakai kalimat yang paradoks, seperti "Setiap orang yang meninggikan diri akan direndahkan, dan setiap orang yang

${ }^{24}$ Stein, 7 ff. 
merendahkan diri akan ditinggikan" (Lukas 14:11). Tuhan Yesus juga menggunakan irony atau ejekan, misalnya ketika berbicara dengan orang Farisi tentang kebutuhan akan keselamatan dan kebenaran, "... bukan orang yang sehat yang memerlukan tabib, tetapi orang sakit" (Lukas 5:31). Kemudian metonymy, misalnya, "Juga di kota-kota lain, Aku harus memberitakan Injil, ..." (Lukas 4:43). Lalu synedoche, misalnya, "Pada-Ku ada makanan yang tidak kamu kenal" (Yohanes 4:32). Atau anthitesis, "Jika seorang ingin menjadi yang terdahulu, hendaklah ia menjadi yang terakhir dari semuanya dan pelayan dari semuanya," (Markus 9:35). Bahkan exclamation, misalnya dalam Matius 23, "Celakalah kamu, hai ahli-ahli Taurat dan orang-orang Farisi, hai kamu orang-orang munafik ...". Tetapi Dia juga menggunakan apostrophe atau tanda-tanda, misalnya, "Celakalah engkau hai Khorazim! Celakalah engkau hai Betsaida! Karena jika Tirus dan Sidon terjadi mukjizat-mukjizat yang telah terjadi di tengah-tengah kamu, sudah lama mereka bertobat dan berkabung ..." (Matius 11:21-22).

Tuhan Yesus juga memakai allusion (sindiran/kiasan). Contoh: "Rombak Bait Allah ini, dan dalam tiga hari Aku akan mendirikannya kembali." (Yohanes 2:19). Tuhan Yesus juga memberikan "reward" atau hadiah melalui pengajaran-Nya yang dipakai untuk mendorong murid atau pengikut-Nya untuk mengambil langkah yang konkret. Ayat yang paling terkenal adalah Yohanes 3:16 (terkait dengan percakapan dengan Nikodemus) dan Yohanes 4:13,14 (percakapan dengan perempuan Samaria) tentang air kehidupan. Demikian pula ketika Petrus menanyakan apa upahnya kalau mengikut Dia karena telah meninggalkan segala sesuatu, maka Tuhan Yesus menjawab bahwa dia akan mendapat upahnya di surga.

Kesembilan, Tuhan Yesus meminta mereka untuk meneladani dan mengikut-Nya secara pribadi. Murid-murid dan para pengikut-Nya setiap hari melihat dan mengamati langsung apa 
yang dikatakan dan dilakukan oleh Tuhan Yesus. Sehingga sebenarnya tidak ada alasan bagi mereka untuk menolak atau tidak mau percaya dan mengikuti Dia. Demikian pula bagi para pendidik, mereka semestinya melakukan apa yang mereka katakan dan mengatakan apa yang seharusnya dilakukan.

Melihat ini semua, maka tentu saja tidak serta-merta semua pendidik bisa menjadi pendidik atau pengajar yang baik. Mengajar memerlukan keterampilan. Eavey benar sekali ketika mengatakan bahwa "mengajar adalah suatu seni" ${ }^{25}$ Untuk itu dalam mengajar harus memerhatikan beberapa faktor penting yang saling berkaitan. Menurut Eavey ada tiga faktor utama, ${ }^{26}$ yaitu faktor: murid (terkait dengan soal kematangan, sebagai pribadi yang berkembang, kemampuan, intelektualitas dsb.); subjek atau materi pengajaran (termasuk di dalamnya apakah bisa memberikan pengalaman yang baru bagi murid); dan pendidik, sebagai pribadi yang mendorong dan membimbing para murid untuk mengalami hal-hal baru untuk dapat berkembang dan bertumbuh dalam kemajuan yang diharapkan. Khususnya bagi seorang pendidik, dibutuhkan sejumlah persyaratan yang harus dipenuhi sehingga dia bisa menjalankan tugasnya dengan baik. Penulis sangat setuju dengan Daniel Lenox Barlow ${ }^{27}$ yang menulis dalam bukunya, "Educational Psychology: The Teaching-Learning Process" tentang kriteria-kriteria para pendidik Kristen, yang menurutnya perlu memiliki kriteria-kriteria sebagaimana dijelaskannya melalui akronim CHAMPIONS yang merupakan kependekan dari:

C_Christ centered. Seorang pendidik yang baik akan dapat dilihat dan diukur dari sampai sejauh mana ia telah menjadikan Kristus

25 C.B. Eavey, Principles of Teaching for Christian Teachers (Grand Rapids, Michigan: Zondervan Publishing House, 1966), 234.

26 Ibid., 234.

27 Daniel Lenox Barlow, Educational Psychology: The Teaching Learning Process (Chicago: Moody Press, 1985), pp. 220-221. Bahan ini telah diringkas oleh Penulis. 
sebagai pusat dalam kehidupan mereka. Kristosentris atau egosentris?

H-Historically knowledge. Allah adalah pusat dari sejarah. Pendidik Kristen bukan saja memahami sejarah dunia, melainkan harus mengerti benar bagaimana Allah berkarya dalam dunia ini melalui orang-orang percaya.

A-Affectively wholesome. Seorang pendidik harus memiliki emosi yang sehat dan mampu mengontrolnya. Ini penting, oleh karena itu mutlak harus berada di bawah kontrol Roh Kudus. Itulah sebabnya maka pendidik harus bisa mengasihi peserta didiknya, dan terlebih kepada Allah sendiri yang telah menyelamatkannya.

M-Morally upright. Seorang pendidik harus memiliki moral, mental dan martabat yang baik dan tulus. Integritas moralnya berdasar serta bersumber pada firman Allah yang "jauh berada di lubuk hatinya". Dia haruslah seorang yang bisa dipercaya karena memiliki karakter kristiani yang baik.

$\mathbf{P}$-Physically able. Secara fisik harus cakap dan terampil untuk melaksanakan tugas-tugasnya. Seorang pendidik juga harus menyadari bahwa tubuhnya adalah Bait Roh Kudus, sehingga dia harus selalu menjaga dan memelihara tubuhnya untuk tetap sehat sehingga mampu untuk terus melaksanakan tugasnya dengan baik dan bertanggung jawab.

I-Intelectually mature. Kematangan intelektual merupakan salah satu wujud kematangan kemampuan kognitifnya. Ia haruslah seorang yang cakap dalam berpikir, cara pandang dan menilai, mendengar, memecahkan masalah, dsb.

O-Oriented to his profession. Seorang pendidik harus selalu berorientasi pada profesinya sebagai seorang pendidik Kristen yang taat dan mengasihi Tuhan, sehingga dapat mengasihi para peserta didiknya. Seluruh orientasi dan cara pandangnya terhadap peserta didik harus didasarkan pada panggilan dan 
kasih Yesus Kristus terhadap dirinya. Dengan demikian maka barulah dia akan dimampukan oleh Tuhan untuk mendidik peserta didiknya dengan baik.

N-Notable in his relationship. Pendidik haruslah seorang yang terpandang dan memiliki pergaulan serta relasi yang baik dengan semua orang. Dia harus bisa menjadi contoh bagi orang lain. Hal itu disebabkan oleh karena Roh Kudus sendirilah yang menguasai dan mengubah hidupnya. Sehingga orang lain bisa menyaksikan buah-buah Roh Kudus yang terpancar dari kehidupannya. Ia tahu harus berbuat apa dan bagaimana terhadap orang lain sesuai dengan karakter kekristenannya. Ia tahu bagaimana harus mengasihi murid dan sesamanya karena ia mencintai dan dicintai Tuhan.

S-Spiritually discerning. Yakni memiliki ketajaman rohani karena hubungan pribadinya yang akrab dengan Tuhan sehingga dia mampu membedakan antara yang baik dan yang jahat; antara kebenaran dan ketidakbenaran, kekudusan dan dosa, dsb. Ini akan diperoleh ketika seorang pendidik benar-benar menyukai firman Tuhan dengan merenungkannya melalui persekutuan pribadinya setiap hari; sehingga ia bukan hanya "mengetahui" firman Tuhan dan kebenarannya, melainkan juga harus mengalami dan memilikinya.

Penulis merekomendasikan bahwa kesembilan hal tersebut perlu dimiliki oleh setiap pendidik Kristen. Tuhan Yesus adalah satu-satunya Pendidik yang paling kreatif dan inovatif dalam pengajaran-Nya. Tidak pernah ada satu pelajaran pun yang dilakukan oleh Tuhan Yesus yang bersifat stereotip. ${ }^{28}$ Dia tidak bisa disejajarkan atau disetarakan dengan ahli pendidikan mana pun dan kapan pun. Ide-ide-Nya sangat orisinal, sehingga para ahli sesudahNya-termasuk di zaman modern ini-sebenarnya hanya mengembangkan dari apa yang sudah dilakukan oleh Tuhan Yesus

28 Michael S. Lawson \& Robert J. Choun, Jr. Directing Christian Education: The Changing Role of The Christian Education Specialist ( Chicago: Moody Press, 1992), 32. 
sebelumnya. Tentu tidaklah berlebihan jika pada akhirnya Price mengatakan bahwa "tidak pernah ada orang yang mengajar seperti Yesus, karena semua metode yang kita pakai sekarang ini semuanya telah dipakai oleh Tuhan Yesus, sekurang-kurangnya dalam bentuk yang sederhana" 29

\section{Prinsip dan Penerapan Metode Pengajaran Yesus}

Meskipun banyak pilihan metode yang bisa dipakai, namun seorang pendidik tidak bisa lalu seenaknya atau secara sembarangan memakai metode tertentu. Berkaitan dengan metode, Cully menjelaskan demikian, "Method is everything which a teacher does to teach and through which a pupil learn. Methods are ways of communication." ${ }^{30}$ Jadi dapat dikatakan bahwa metode adalah segala upaya atau cara yang dipakai oleh seorang pendidik, dalam pengajaran di mana para peserta didik dapat belajar dan mengerti, karena metode adalah cara atau jalan komunikasi yang baik. Menurut Snyder, agar metode yang dipakai itu dapat dimanfaatkan secara efektif, maka seorang pengajar paling tidak terlebih dahulu harus memertimbangkan lima hal mendasar seperti berikut: ${ }^{31}$ Pertama, apakah metode yang dipakai itu memang sejalan dengan filosofi mengajar pendidik atau pendidik yang bersangkutan? Sebagai seorang pendidik Kristen atau bahkan pendidik sekolah teologi, pemakaian metode harus dapat memertajam peran dan pengenalan terhadap Roh Kudus dalam proses belajar-mengajar yang berlangsung dan dalam kehidupan pribadi mereka. Kedua, apakah metode itu memang cocok dengan tujuan pengajaran itu sendiri? Hal ini dikarenakan tidak semua

29 Price, 99. 1966), 8.

${ }^{30}$ Irish V.Cully, Ways to Teach Children (Phliladelphia: Fortrees Press,

31 Alton G. Snyder, Teaching Adults (Philadelphia: The Judson Press, 1960), 34-35. 
metode itu pasti cocok untuk dipakai pada semua mata pelajaran. Masing-masing harus disesuaikan dengan isi dan tujuan pengajaran yang telah ditetapkan. Ketiga, dan ini yang penting, yaitu bahwa metode harus bisa dipahami baik oleh pengajar maupun yang diajar (pendidik-peserta didik). Jangan sampai terjadi pendidik menganggap metode yang dipakai adalah yang paling tepat, padahal peserta didik kurang bisa mengikuti karena kurang memahaminya. Keempat, apakah metode itu juga dapat mendorong adanya pertumbuhan kelompok atau kelas? Apakah kelas lalu terdorong untuk bertumbuh dan meningkat menjadi kelompok yang matang, mandiri dan kuat? Kelima, apakah metode itu dapat disesuaikan dengan situasi dan kondisi dalam proses belajar-mengajar? Artinya bukan metode yang kaku, tapi masih dapat diubah dalam satu kondisi atau situasi tertentu kalau memang mengharuskan demikian.

Tidak jauh berbeda dengan Snyder, Kristianto, juga mengatakan bahwa sebelum seorang pendidik menyampaikan materi pengajarannya, terlebih dulu harus memerhatikan hal-hal berikut: ${ }^{32}$ Pertama, sebelum menentukan metode yang akan dipakai, dia harus menyiapkan bahan pelajaran yang akan disampaikan di kelas dengan baik. Kedua, memilih metode yang sesuai. Faktor yang sangat menentukan seorang pendidik memilih metode adalah usia peserta didik, materi yang disajikan dan waktu penyelenggaraan. Ketiga, pendidik menggunakan metode secara bervariasi, tidak monoton, meskipun itu mungkin metode yang paling baik yang bisa digunakan. Keempat, pendidik menggunakan metode yang cocok dan dapat membuka komunikasi dengan peserta didik. Kelima, pendidik harus mengatur tempat sebagai fasilitas yang akan digunakan dalam sebuah metode.

Terkait dengan soal pemilihan metode yang hendak dipakai oleh pendidik, menurut Sahardjo, harus menyesuaikan dengan jenis belajar yang ada pada tujuan pelajaran seperti pada saat menentukan strategi pengajaran. Ada beberapa prosedur untuk memilih metode. 1) Dari setiap tujuan, apakah kita berurusan dengan problem

32 Paulus Lilik Kristianto, Prinsip \& Praktik Pendidikan Agama Kristen (Jogyakarta: Penerbit Andi, 2006), 84. 
informasi, kinerja atau kombinasi antara keduanya? 2) Bagi setiap tujuan, pertimbangkan golongan dasar pengetahuan (bersifat informasi faktual, konsep atau prinsip atau kombinasi) atau kecakapan (reproduktif sederhana maupun rumit) yang hendak diajarkan? 3) Berdasarkan kedua hal itu, kemudian putuskan metode mana yang paling cocok, penemuan atau pemaparan. 4) Pertimbangkan pembatasan praktis yang tak mungkin disingkirkan, baik faktor sumberdaya, target populasi maupun sistem yang lebih luas. 5) Selanjutnya pilihlah beberapa metode yang patut digunakan. ${ }^{33}$ Dengan mengutip pendapat Romiszowski, lebih lanjut Sahardjo mengatakan bahwa pemilihan metode sesuai dengan jenis belajar adalah: a) Belajar dan mengajar fakta, b) Belajar dan mengajar prosedur, c) Belajar dan mengajar konsep, d) Belajar dan mengajar prinsip, dan e) Belajar dan mengajar kecakapan. ${ }^{34}$

Sasaran akhir dari penggunaan metode menurut Iris V. Cully adalah untuk membantu para murid agar dapat memenuhi kehendak Allah dan rencana-Nya dalam relasinya terhadap pribadi dan sesama manusia, serta dapat menyaksikan imannya dalam berbagai cara. ${ }^{35}$ Jadi seorang pendidik atau pendidik tidak boleh menggunakan metode secara serampangan, melainkan harus dipersiapkan secara matang dan disesuaikan dengan situasi dan kondisi pembelajaran, baik yang berhubungan dengan materi maupun objek belajar.

33 Hadi P. Sahardjo, Pendidikan Kristen: Prinsip Pendidikan yang Mengakar Pada Iman Kristen dan Kebenaran Alkitab (Batu: Departemen Literatur YPPII, 2007), 169.

${ }^{34}$ Ibid., 170.

35 Iris V. Cully, Ways to Teach Children (Philadelphia: Fortrees Press, 1966), 17-18. 


\section{Peningkatan Profesi Melalui Training}

Banyak pendidik sekolah teologi atau seminari yang merasa sudah cukup dengan bekal dan ilmu yang dimiliki. Anggapan bahwa peningkatan pengetahuan dan keterampilan itu cukup didasari oleh bekal ilmu yang sudah dipelajari sebelumnya serta pengalaman ditambah dengan membaca-baca buku itu sudah cukup. Padahal untuk pendidik atau pendidik sekolah-sekolah atau perpendidikan tinggi non teologi (sekular), kemampuan mengajar mereka selalu ditingkatkan melalui berbagai penataran, mulai dari bagaimana cara membuat model satuan pelajaran atau kontrak perkuliahan, cara membuat kisi-kisi, pengenalan dan aplikasi metode-metode pembelajaran sampai dengan penataran soal pengelolaan kelas, pengelolaan sekolah, administrasi/ manajemen pendidikan, profesi kependidikan dan lain-lain. Bahkan sekarang dengan adanya sistem atau program sertifikasi, para pendidik atau pendidik sekolah-seolah non teologi telah dilengkapi dengan hal-hal yang terkait dengan masalah tersebut. Paling-paling yang diikuti oleh para pendidik sekolah teologi adalah program PEKERTI dan Applied Approach (AA) guna mendapatkan sertikat mengajar di perpendidikan tinggi. Padahal menurut Tim Siemens $\mathrm{dkk}^{36}{ }^{36}$ training atau penataran untuk para pemimpin dan pendidik (pendidik-dan pendidik) Kristen itu amat penting guna meningkatkan kemampuan dan keterampilan mengajarnya, bukan terbatas hanya pada soal penguasaan bahan/materi pengajaran, melainkan juga dalam pemakaian metode yang tepat.

Menurut hasil penelitian yang dilakukan oleh dua orang profesor dari Denver Seminary, Brown dan Williams, sebagaimana dikutip oleh Tim Siemens dkk., mengatakan bahwa ada paling tidak ada sepuluh tugas penting yang berkaitan dengan pelayanan pendidikan dengan urut-urutan sebagai berikut:

36 Tim Siemens, Roy Reiswig, Gordon West, "Training Christian Leaders and Teachers: Principles and Practice" dalam Michael S. Lawson \& Robert J. Choun, Jr. Directing Christian Education (Moody Press: Chicago, 1992), 139. 


\begin{tabular}{l|l}
$\%$ & Tugas \\
\hline 97 & Mendemonstrasikan dan mampu untuk menjangkau \\
& murid/orang \\
95 & Melatih para pendidik \\
94 & Merekrut pendidik \\
94 & Mendemonstrasikan dan mampu bekerja sama dengan para \\
& pendidik dan pekerja lainnya \\
93 & Mendemonstrasikan kemampuan seni mendengar \\
93 & Merencanakan dan memimpin training para pendidik \\
92 & Membimbing para pendidik lepas/honorer \\
91 & Memimpin kelompok \\
89 & Menggunakan hukum-hukum dan prinsip-prinsip belajar \\
87 & Meningkatkan training untuk para pendidik
\end{tabular}

Dari sini nampak jelas bahwa dari sepuluh tugas, ada tiga hal yang berkaitan langsung dengan soal training, yaitu pada nomor dua (melatih para pendidik), nomor enam (merencanakan dan memimpin training para pendidik) dan nomor sepuluh (meningkatkan training untuk para pendidik). Dengan kata lain, peningkatan kemampuan mengajar bagi para pendidik atau pendidik itu menempati posisi yang sangat penting, bahkan menjadi suatu keharusan. Seorang pendidik atau pendidik yang tidak mau meningkatkan pengetahuan dan keterampilan mengajarnya, maka ia akan ketinggalan dan tidak bisa maju. Dengan berbagai training yang diadakkan dan diikuti oleh para pendidik atau pendidik, maka mereka pasti berkembang dan maju.

\section{Menguasai dan Menerapkan Metode-metode Pengajaran Yesus}

Pengetahuan tanpa penguasaan dan penerapan tidak ada artinya. Oleh karena itu seorang pendidik harus memiliki dan menerapkan ketiga-tiganya, yaitu mengetahui, menguasai serta menerapkan metode peragaan, metode drama, metode cerita,

${ }^{37}$ Ibid., 139-140 
metode ceramah, metode bertanya dan metode diskusi dalam pengajarannya. Dalam penerapannya, pendidik atau pendidik perlu menerapkan pengajaran yang demokratis, seperti dikemukakan oleh Leon Marsh yang mengatakan bahwa apabila murid diajar dengan gaya atau iklim yang demokratis, maka gambaran diri (self image) nya pasti juga akan dapat berkembang dengan lebih baik. ${ }^{38}$ Bagaimana pun harus diakui, bahwa seorang pendidik yang baik dan penuh perhatian akan disenangi oleh para peserta didiknya. Seorang pendidik adalah juga sebagai agen kasih Allah bagi para peserta didiknya.

Adapun ciri-ciri pengajaran yang demokratis itu menurut Marsh $^{39}$ adalah sebagai berikut: pertama, pendidik menggalakkan partisipasi peserta didik dalam interaksi di kelas; kedua, pendidik mendelegasikan tanggung jawab kelas kepada peserta didik; ketiga, pendidik tidak menerapkan prosedur yang kaku; keempat, pendidik mampu menciptakan interaksi dalam kelas antara pendidik dan peserta didik dengan sangat baik; kelima, peran pendidik dalam kelas ditentukan oleh kebutuhan dalam kelas, dan bukan sematamata yang telah digariskan oleh pendidik sendiri; keenam, pendidik yang demokratis akan mengelola kelasnya dengan fleksibel, tidak kaku dalam menggunakan pendekatan langsung maupun tidak langsung dalam proses pembelajaran terhadap peserta didiknya.

Dari sini nampak bahwa tujuan pemakaian metode dalam pengajaran itu adalah supaya baik peserta didik maupun pendidik merasa senang dan nyaman dalam mengajar maupun belajar yang tercipta dalam suasana belajar yang kondusif untuk hasil yang optimal.

\section{Menguasai Hukum Mengajar}

Dalam karya klasiknya, The Seven Laws of Teaching (sudah diterjemahkan ke dalam bahasa Indonesia oleh Penerbit Gandum Mas, Malang dengan Judul “Tujuh Hukum Mengajar”, pen.), John

\footnotetext{
${ }^{38}$ Marsh, 252.

${ }^{39}$ Ibid., 252.
} 
Milton Gregory ${ }^{40}$ menuliskan ketujuh hukum tersebut yang secara ringkas dapat dituliskan sebagai berikut:

1. Hukum pendidik (istilah ini tetap dipertahankan seperti aslinya, pen.) bunyinya demikian, "Seorang pendidik harus memahami bahan yang akan diajarkan.” Kalimat ini memiliki falsafah yang sangat mendalam, yaitu bahwa pendidik seharusnya memahami terlebih dahulu apa yang akan diajarkan, dan tidak mengajarkan apa yang belum diketahui atau yang belum dipahaminya.

2. Hukum murid, "Seorang murid adalah orang yang memiliki minat penuh untuk memerhatikan pelajaran yang diberikan oleh pendidik".

3. Hukum bahasa. "Bahasa pengantar yang dipakai antara pendidik dan murid harus dimengerti oleh kedua belah pihak." Jadi bahasa yang dipakai antara pendidik dengan murid harus bahasa merupakan bahasa komunikasi yang sederhana dan mudah dimengerti.

4. Hukum pelajaran. "Bahan pelajaran yang akan diberikan harus dapat diterangkan dengan menunjukkan segi-segi kebenaran yang sudah diketahui oleh murid; apa yang belum diketahui harus dijelaskan melalui apa yang sudah diketahuinya." Dengan kata lain, bahan yang diberikan harus apa yang diketahui oleh murid. Jadi pendidik tidak akan mengajar sesuatu yang tidak ada hubungannya dengan murid.

5. Hukum mengajar. "Mengajar berarti merangsang dan memakai pikiran murid untuk menangkap buah pikiran atau menguasai segi kesenian yang dikehendaki." Merangsang berarti membangkitkan daya pikir peserta didik untuk mengerti dan memahami mengenai apa yang diajarkan. Jadi ini merupakan tugas pendidik.

6. Hukum belajar. "Belajar berarti berpikir sampai mengerti sendiri dan menerima suatu gagasan atau segi kebenaran yang

${ }^{40}$ Gregory, 19 dyb. 
baru; atau membiasakan diri melakukan suatu bidang kesenian atau keterampilan baru." Ini merupakan tugas murid.

7. Hukum evaluasi atau mengulang. "Ujian dan bukti mengenai keberhasilan pengajaran yang telah diberikan, proses penyelesaian dan pengulangan, sifatnya adalah mengulangi, memikirkan kembali, memahami kembali dan menciptakan kembali kemudian menerapkan bahan yang telah diajarkan, yaitu pengetahuan dan cita-cita serta kesenian yang telah disampaikan." 41

Ketujuh hal tersebut sangat berpengaruh terhadap tingkat keberhasilan dalam proses pembelajaran, sehingga peserta didik pun akan lebih mudah termotivasi oleh pendidik yang memiliki sifat dan kemampuan seperti yang diharapkan oleh mereka.

\section{Akulturasi atau Penyesuaian Diri ${ }^{42}$}

Dalam dunia pendidikan Kristen, termasuk pendidikan di gereja perlu mengadakan berbagai penyesuaian dalam pelaksanaannya. Mereka ini memiliki latar belakang kepercayaan yang berbeda (baik karena berpindah agama, baru percaya, tingkat kepercayaan atau iman) dalam keluarga yang berbeda, dsb. Bahkan dalam berbagai hal juga berbeda, baik dari segi intelektual, gender, usia, kebudayaan dan tingkat sosial, lingkungan. Karena itu ada kalanya-bagi gereja-gereja yang mampu-orang-orang yang tinggal di daerah pinggiran atau daerah tertentu perlu diadakan penjemputan dengan kendaraan gereja. Orang-orang seperti ini perlu mendapatkan perhatian dan pelayanan yang disesuaikan dengan latar belakang mereka tadi. Oleh karena itu dalam penetapan dan pengembangan kurikulum harus selalu dipersiapkan untuk menghadapi segala perkembangan dan situasi yang baru dan berbeda dalam jemaat. Hal yang sama juga terjadi dalam pendidikan di sekolah, ketika seorang pendidik diperhadapkan dengan kondisi peserta didik dengan latar belakang yang beragam.
41 Ibid., 21.
${ }^{42}$ Marsh, 252-253. 


\section{Interes $^{43}$}

Setiap pendidik pasti akan memiliki motivasi yang kuat untuk belajar apabila memiliki interes terhadap hal tersebut. Interes atau minat, atau ketertarikan terhadap sesuatu dengan sendirinya akan mendorong individu untuk melakukan dengan baik, termasuk terhadap hal-hal yang bagi orang lain barangkali dianggap sulit. Timbulnya ketertarikan atau interes ini tidak terlepas dari peran seorang pendidik yang memiliki perhatian penuh kepada para muridnya, di mana ia tidak hanya memerintah atau meminta seorang murid melakukan sesuatu yang diharapkannya, melainkan dirinya sendiri memberi contoh dan melakukannya. Peserta didik akan senang melakukan sesuatu yang baru apabila pendidik juga mau melakukan apa yang ingin dilakukan oleh peserta didik.

\section{Pengalaman Hidup ${ }^{44}$}

Pengalaman hidup, khususnya kehidupan Kristen yang telah diselamatkan dan dilahirkan kembali melalui kuasa Roh Kudus, merupakan salah satu komponen penting dalam proses pendidikan. Karena dari sini ia akan terus berjalan menurut panggilan Tuhan dalam setiap disiplin kehidupannya. Disiplin berarti menjadi peserta didik dalam sekolah Kristus. Artinya ia harus selalu belajar dan membelajarkan diri sebagai seorang murid yang memuridkan orang lain. Dengan demikian maka pengalaman hidupnya sebagai orang yang sudah lahir baru akan berpengaruh pula terhadap proses pembelajarannya melalui kuasa Roh Kudus. Dia akan mengajar dengan penuh kasih seperti Kristus telah mengasihinya. Seorang pendidik harus bisa menjadikan diri sebagai alat peraga hidup yang siap dipertontonkan kepada peserta didik. Dirinya akan menjadi
${ }^{43}$ Ibid., 257-8
${ }^{44}$ Ibid., 258-9 
contoh, teladan, potret hidup yang menghidupkan. Peserta didik akan belajar dari kehidupan pendidik yang seperti ini.

Pada saat kita telah menerima panggilan Tuhan Yesus, sebenarnya kita telah menerima amanat untuk melayani, termasuk mengajar. Panggilan pertama kepada para murid-Nya adalah "Mari, ikutlah Aku!" (Matius 9:9) yang ditutup dengan satu perintah atau amanat, "Pergilah ..., jadikanlah ..., baptislah ..., dan ajarlah...!" (Matius 28:28). Ketika Tuhan Yesus mengutus para murid-Nya, Ia memakai analogi "Seperti Bapa telah mengutus Aku, demikianlah Aku mengutus engkau..." (Yohanes 17:18). ${ }^{45}$ Dengan kata lain, seorang pendidik adalah seorang utusan bagi para peserta didik.

\section{Kemampuan Meningkatkan Motivasi}

Cara kerja otak manusia itu sangat unik. Semakin banyak stimulus yang diterimanya, akan semakin memertajam memori seseorang. Merriam dan Caffarella mengatakan bahwa orang dewasa juga dapat memertajam ingatan dan belajarnya melalui memory aids dalam kegiatan belajarnya. ${ }^{46}$ Kegiatan di sini termasuk bagaimana caranya individu itu belajar sendiri dan apa yang diperolehnya melalui pembelajaran dengan berbagai metode yang digunakannya itu. Individu dapat ditingkatkan motivasinya melalui pemberian valensi negatif dan valensi positif. Yaitu stimulasi pemberian kondisi untuk tidak mengulangi suatu tindakan berdasarkan pengalaman yang merugikan, atau terus mencoba mengulangi suatu tindakan yang dirasakan selalu memberikan kenyamanan atau menguntungkan. Oleh karena itu menurut Gangel-yang mengutip pendapat Krathwohl, ${ }^{47}$ yang memaparkan pendapatnya

45 Yohanes 17:18.

46 Sharan B. Merriam \& Rosemary S. Caffarella, Learning in Adulthood: A Comprehensive Guide (San Fransisco: Jossey-Bass Publishers, 1991), 166.

47 Kenneth O. Gangel \& Howard G. Hendricks, The ChristianE Educator's Handbook on Teaching: A Comprehension Resource on Distinctiveness of True Christian Teaching (Grand Rapids, Michigan: Baker Books, 2003), 152153. 
berdasarkan taksonomi Bloom-mengatakan bahwa tujuan pendidikan yang harus dicapai dalam pendidikan Kristen adalah: cognitive, affective dan conative (bukan psikomotor sebagaimana diungkapkan oleh Bloom). Cognitive berkaitan dengan apa yang seharusnya diketahui oleh peserta didik, affective berhubungan dengan apa yang dirasakan, sementara conative berhubungan dengan apa yang semestinya hendak dilakukan. Apakah hubungan antara tiga domain belajar dengan tingkah laku individu? Berikut adalah gambaran contoh konkret yang terjadi dalam kehidupan sehari-hari:

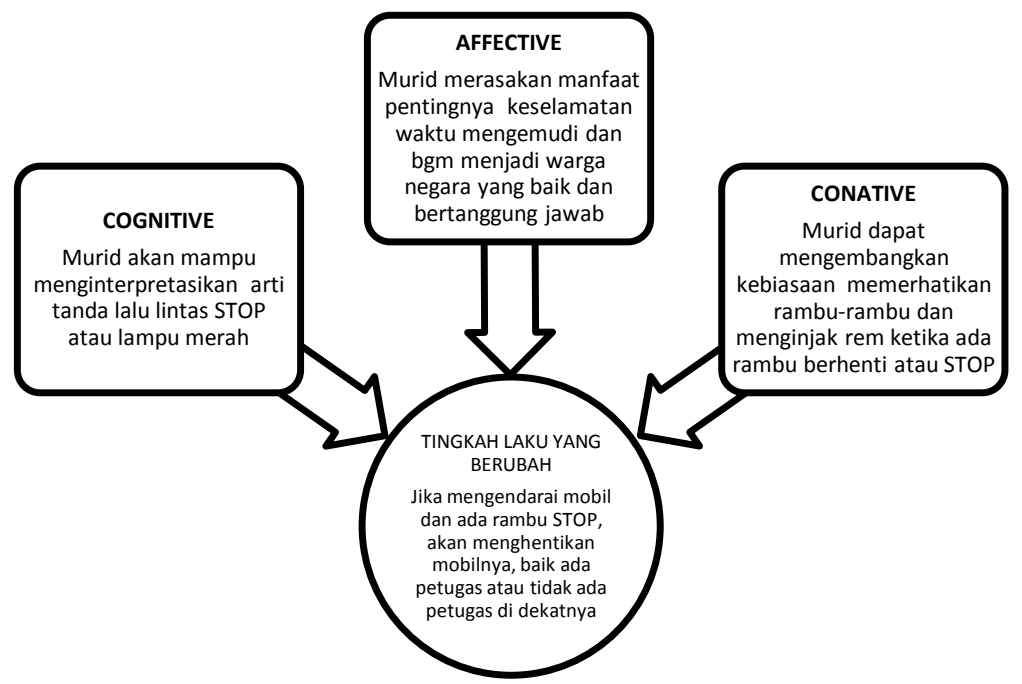

Dari diagram ini nampak, bahwa individu (dalam hal ini murid) akan dapat mengalami perubahan dalam sikap, tingkah laku dan kebiasaan hidupnya sehari-hari apabila dia telah mengerti, memahami makna atau nilai guna dari suatu kebenaran dan bisa mengaplikasikannya dalam kehidupannya sehari-hari melalui apa yang dilihat, dipelajari serta melalui contoh dan teladan orang-orang maupun lingkungan sekitarnya. 
Selanjutnya Leon Marsh melontarkan pertanyaan, mengapa seorang pendidik harus memberikan perhatian yang memadai terhadap para murid atau peserta didik? Jawabannya adalah karena mereka itu memiliki nilai yang sangat penting dan berharga, sebagaimana dirangkum oleh Leon Marsh berikut ini: ${ }^{48}$

1. Allah perduli untuk setiap hidup yang terpisah (God cares for each separate life).[ Matius 10:30-31].

2. Peserta didik itu lebih penting daripada semua lembaga/ institusi (The learner is more important than all institution).

[Matius 12:12; Markus 2:27].

3. Peserta didik itu lebih berharga dibandingkan dengan seluruh ciptaan lainnya. (The learner is more important than the whole created order). [ Markus 8:36; Matius 6:25; Lukas 12:15.].

4. Penyitaan/perbuatan sia-sia yang dilakukan oleh peserta didik dari kehidupan yang sebenarnya itu menyesatkan dan merugikan (Forfeiture by a learner of his true life is deplored). [Markus 8:37; 9:43; Matius 16:26; 18:8; Lukas 9:25].

5. Peserta didik yang paling remeh pun, tetap berharga bagi Allah (The most insignificant learner is precious to God). [Matius 18:10; 18:12-24; Lukas 15:4-7].

6. Pribadi yang terburuk sekalipun, masih bernilai di mata Allah. (The worst person still has value in God's sight) [Matius 11:19; Markus 2:15; Lukas 5:30-32; 15:3-10; 15:11-32].

Apa yang dikatakan oleh Leon Marsh benar sekali. Melalui keenam butir pernyataannya itu dalam kaitannya dengan pendidikan ia menegaskan bahwa: pertama, Allah peduli terhadap setiap bagian dari kehidupan peserta didik; kedua, peserta didik itu lebih penting jika dibandingkan dengan institusi-institusi atau lembaga yang ada. Ketiga, peserta didik lebih penting jika dibandingkan dengan seluruh ciptaan lainnya. Keempat, adalah suatu kerugian besar dan harus disesali apabila peserta didik 
kehilangan arti kehidupan yang sebenarnya. Kelima, peserta didik yang dianggap paling rendah atau remeh sekalipun sangat mulia di hadapan Tuhan. Keenam, peserta didik yang paling jelek sekalipun, tetap sangat berharga dalam pandangan Allah. ${ }^{49}$

Gangel menekankan bahwa analisis terakhir dari Amanat Agung Tuhan Yesus dalam Matius 28:18-20 (ditambah dengan Kisah Para Rasul 2:42) adalah amanat untuk mengajar. Bahkan untuk menegaskan betapa pentingnya amanat itu, Gangel menggarisbawahi peringatan Murch terhadap para pendidik untuk memilih antara "mengajar atau binasa" Arti dari pernyataan itu sangat jelas, yaitu kalau para pendidik atau pemimpin Kristen tidak mau mengajar, maka berarti membiarkan mereka akan binasa. Sehingga ini bukan lagi suatu pilihan, tetapi keharusan. Menurut William, orang-orang akan bisa beriman kepada Kristus hanya melalui pengajaran firman Allah dan kuasa Roh Kudus. ${ }^{51}$ Dengan demikian pendidikan Kristen baru bisa dikatakan Kristen jika para pendidik dan peserta didik benar-benar bergantung kepada pekerjaan Roh Kudus dalam lingkungan pembelajaran mereka. Adalah Kristen jika tujuan dan sasarannya adalah untuk kemuliaan dan kehormatan bagi nama Tuhan dan kerajaan-Nya. Adalah Kristen jika kurikulum itu dikembangkan berdasarkan pengajaran firman Allah serta pemahaman teologi alkitabiah. Itu adalah Kristen ketika terdapat pemahaman yang menyeluruh dengan perspektif bahwa Allah yang memegang kendali, dan bahwa para pendidik maupun peserta didik

${ }^{49}$ Marsh, 1.

50 Gangel, Membina Pemimpin Pendidikan Kristen (terj.) (Malang: Gandum Mas. 1998), 31.

51 Dennis E. Williams, "Christian Education" dalam Michael J. Anthony (Ed.). Evangelical Dictionary of Christian Education (Grand Rapids, Michigan: Baker Academic, 2001), 132. 
secara tulus mencari kepenuhan keinginan kehendak Allah dan maksud-Nya terhadap segala perkara. ${ }^{52}$

Selanjutnya Williams menjelaskan bahwa yang menjadi tujuan pendidikan Kristen adalah membawa orang-orang untuk diselamatkan melalui iman kepada Tuhan Yesus Kristus, melatih mereka dalam kehidupan pemuridan, serta melengkapi mereka untuk pelayanan Kristen di dunia dewasa ini. Tujuan, sasaran, dan nilai-nilai dari pendidikan Kristen itu bersumber dari dasar teologis alkitabiah.

HADI P. SAHARDJO, menyelesaikan pendidikan teologinya dari SAAT, Malang (B.Th., S.Th., M.A. dan M.Div.) dan Th. M. (ITS, Los Angeles, USA) serta D.Th. (STBI Semarang). Doktorandus (Drs.) di bidang Psikologi Pendidikan dan Bimbingan Konseling dari IKIP (sekarang Universitas) Negeri Malang. Sekarang menjadi dosen tetap dan menjabat sebagai Puket III dan Konselor di STT SAPPI. 